\title{
The distance between larva and cell opening triggers broodcell invasion by Varroa jacobsoni
}

\author{
B Goetz, N Koeniger \\ Institut für Bienenkunde (Polytechnische Gesellschaft), Fachbereich Biologie der JW Goethe- \\ Universität Frankfurt a M, Karl-von-Frisch-Weg 2, 637 Oberursel 1, Germany
}

(Received 13 March 1992; accepted 28 October 1992)

\begin{abstract}
Summary - The effect of the distance between larva and cell opening on Varroa invasion was examined. The infestation of open brood cells depends on this distance and not on larval size. Hence the concentration of a pheromone produced by the larva at a certain age is unlikely to be the only stimulus triggering invasion of brood cells.
\end{abstract}

Apis mellifera / capping behaviour / semiochemical / Varroa infestation

\section{INTRODUCTION}

Varroa mites reproduce in capped brood cells of Apis mellifera. During the last day before cell capping, the mites enter into the brood cells (Ifantidis, 1988; Boot et al, 1990). This links the invasion of Varroa mites to the capping of brood cells by the bees.

Recently Le Conte et al (1990) and Trouiller et al (1991) reported the isolation of pheromones from honey bee larvae composed of aliphatic esters which could evoke capping behaviour. However, the length of the cell also plays a role in capping, as shortened brood cells were capped earlier and elongated cells later compared to normal cells (Goetz and Koeniger, 1992). Some components of larval pheromones (Le Conte et al, 1989; Trouill- er et al, 1991) showed a significant attractivity for Varroa mites. Furthermore, brood cells which protruded above the comb surface showed a higher infestation by mites than control cells (de Ruijter and Calis, 1988). Therefore, the structural features of the brood cell seem to affect brood cell invasion by Varroa mites. We tested brood cells with different cell depths to find out whether the same structural features of the brood cell, which evoke cell capping (Goetz and Koeniger, 1992), also trigger cell invasion of Varroa mites..

\section{MATERIALS AND METHODS}

Combs with worker brood $\left(L_{4}, L_{5}\right)$ of a Varroainfested colony were deep-frozen $\left(-18^{\circ} \mathrm{C}\right)$. On the frozen comb the distance $(A)$ between larva and cell opening of open brood cells was meas- 
ured with a caliper. As criterion for the final stage of cell capping we used a diameter of the cell opening $<4 \mathrm{~mm}$. Then the lanvae were removed and Varroa mites in the brood cells counted. We also checked newly capped cells containing larvae before pupation for Varroa infestation.

For shortening of brood cells we always chose 2 comb areas of $30-70 \mathrm{~cm}^{2}$ with brood cells containing $4-5$ day-old larvae. Wire screens were fixed parallel to both comb surfaces at a distance of $6.5 \mathrm{~mm}$ and $10 \mathrm{~mm}$, respectively (Goetz and Koeniger, 1992). These 2 distances were assigned randomly to the 2 brood areas. The bees adjusted the distance between comb surface and wire screen to "bee space" by shortening the cells. Twenty-four $h$ after attaching the wire screens the combs were deep-frozen. At that time a few of the cells had already been capped. We measured the distance $(A)$ between larval surface and cell opening as described above. In addition, the cell depth was measured by a probe (Goetz and Koeniger, 1992).

\section{RESULTS}

We examined 1299 unmanipulated brood cells from 5 combs of the same colony.
For groups of cells formed according to the distance $(A)$, the Varroa infestation and the percentage of cells with the diameter of the cell opening $<4 \mathrm{~mm}$ was determined (fig 1). At $A>7.5 \mathrm{~mm}$ no mites were found in the brood cells. Infestation started at $A=$ $7.5-7.0 \mathrm{~mm}$ and increased exponentially until the cells were capped. The first cells reached the final stage of capping at $A=$ $5.5-5.0 \mathrm{~mm}$.

In addition to this we examined 401 shortened cells and 377 control cells with wire screens fixed parallel to the comb surface. Both cell types came from 7 combs out of 5 colonies. The data from shortened cells and control cells were analysed separately.

First we formed groups according to the distance $A$ for both of the cell types and determined the Varroa infestation of each group (fig 2). Relative to the distance $A$ there is no difference between the infestation of shortened cells and control cells. Five groups show a higher infestation of shortened cells. In the 2 other groups infestation of control cells is higher.

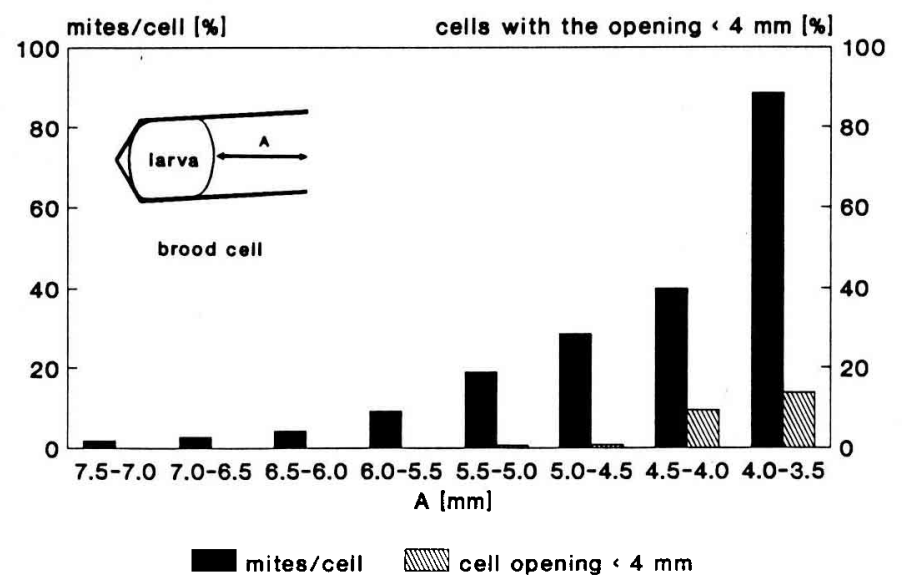

Fig 1. Varroa infestation of open worker brood cells (infestation of capped cells: $100 \%$ ) and percentage of cells with the diameter of the cell opening $<4 \mathrm{~mm}$ as a function of the distance between larva and cell opening $(\mathrm{A}) ; N \geq 20$ for each column. 


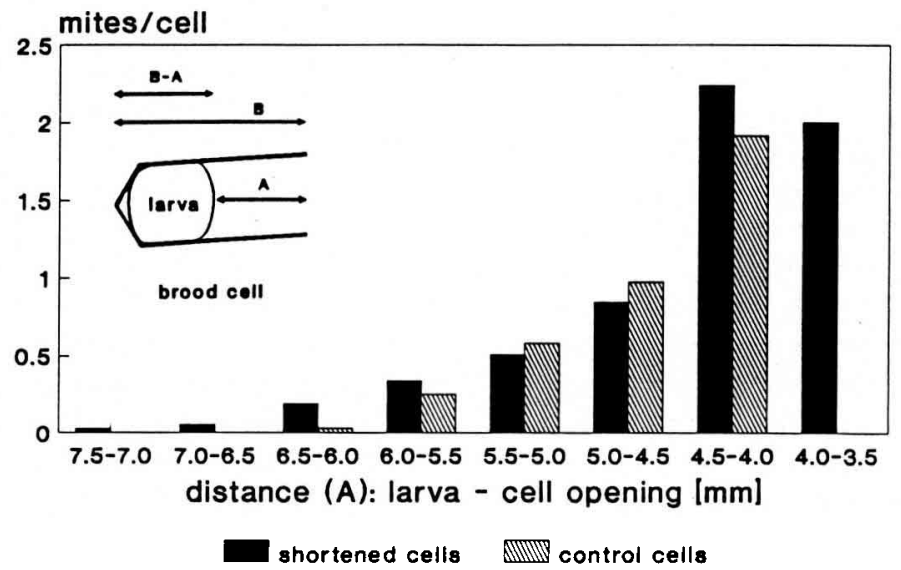

Fig 2. Varroa infestation of open worker brood cells (mites/cell) as a function of the distance between larva and cell opening (A). Wire screens were fixed parallel to the comb surface at 2 different distances (control cells: $10 \mathrm{~mm}$, shortened cells: $6.5 \mathrm{~mm}$ ); $N \geq 15$ for each column.

In a second way of analysing the data we determined the infestation of the cells according to larval size. The difference between cell depth and distance from larval surface to cell opening (B-A) correlates to larval size. We formed groups according to BB-A separately for the 2 cell types (fig 3). Shortened cells show a higher infestation than control cells in each of the 8 groups. The difference is significant (Wilcoxon's test; $P=0.01$ ).

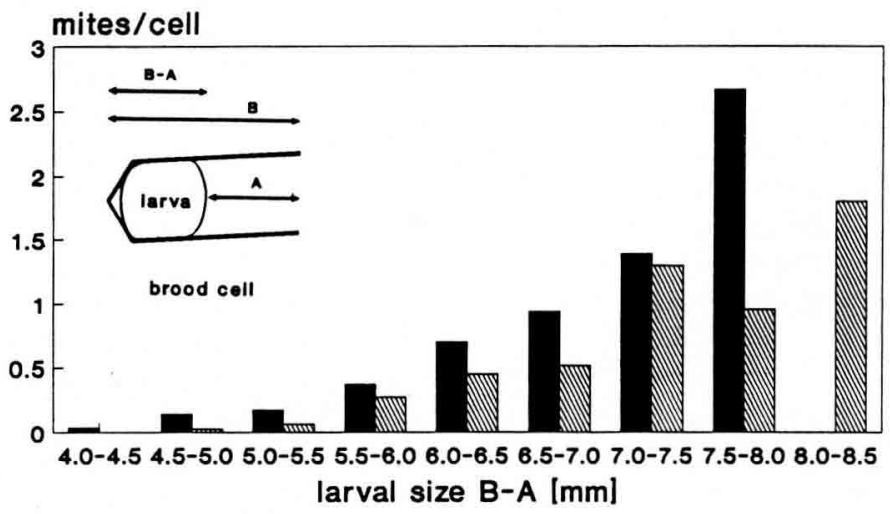

shortened celis control cells

Fig 3. Varroa infestation of open worker brood cells (mites/cell) as a function of larval size (B-A). Wire screens were fixed parallel to the comb surface at 2 different distances (control cells: $10 \mathrm{~mm}$, shortened cells: $6.5 \mathrm{~mm}$ ); $N \geq 10$ for each column. 


\section{DISCUSSION}

Cell capping behaviour starts with the deposition of wax at the rim and its intensity and progress gradually increase. At the final stage (diameter of the cell opening $<4 \mathrm{~mm}$ ) the cell will be closed completely within $30 \mathrm{~min}-1 \mathrm{~h}$ (Meyer and Ulrich, 1952). This stage is reached by the first cells at a distance A of $5.5-5.0 \mathrm{~mm}$. Already some time before, at a distance $A$ of $7.5-7.0 \mathrm{~mm}$ Varroa infestation starts. Brood invasion and cell capping have a parallel time course.

The distance between larva and cell opening affects the number of invaded mites. This distance may trigger invasion behaviour directly. This would be in agreement with Issa et al (1985), who observed that Varroa mites react to the presence of larvae only at a distance $<3-5 \mathrm{~mm}$. The distance may also trigger invasion indirectly. Shortened cells were found to be capped earlier (Goetz and Koeniger, 1992). So, if the invasion depends either on capping behaviour of the bees or on the structure of the cell rim, mites would enter shortened cells earlier. The size of the larvae did not affect invasion. This is in contradiction with the findings of Trouiller et al (1991), who suggests that larger larvae produce more semiochemicals which result in mite invasion and cell capping. When these semiochemicals are important to invasion of Varroa mites, they are not the only factor triggering invasion.

\section{Résumé - La distance entre la larve et l'ouverture de la cellule déclenche l'in- festation du couvain par Varroa jacob- soni. Afin de se reproduire l'acarien Var- roa jacobsoni Oud pénètre dans les cellules de couvain d'abeille (Apis mellifera L) le jour qui précède l'operculation (Ifanti- dis, 1988; Boot et al, 1990). Récemment,}

le Conte et al $(1989,1990)$ et Trouiller et al (1991) ont isolé des phéromones qui provoquaient l'operculation et présentaient une attractivité significative vis-à-vis de $V$ jacobsoni. Mais certaines caractéristiques structurales de la cellule jouent également un rôle important dans l'operculation (Goetz et Koeniger, 1992).

Le diamètre de l'ouverture de la cellule et la distance $A$ entre la larve et l'ouverture de la cellule ont été mesurés sur des rayons congelés de couvain d'ouvrières non operculé, prélevés dans une colonie infestée par $V$ jacobsoni. Les acariens présents dans ces cellules et dans les cellules récemment operculées des mêmes rayons ont été dénombrés (fig 1). Le moment où l'ouverture de la cellule devient inférieure à $4 \mathrm{~mm}$ correspond à peu près au moment où les abeilles intensifient leur activité d'operculation, soit $1 / 2$ à $1 \mathrm{j}$ avant l'operculation complète (Meyer et Ulrich, 1952). À ce stade d'operculation la distance $A$ la plus grande trouvée a été de $5,5-5,0 \mathrm{~mm}$. L'infestation par $V$ jacobsoni a commencé lorsque la distance $A$ a atteint $7,5-7,0 \mathrm{~mm}$ (fig 1).

Sur des rayons congelés présentant des cellules raccourcies (Goetz et Koeniger, 1992) et des cellules témoins, on a déterminé la distance $A$ entre la larve et l'ouverture de la cellule, l'infestation par $V$ jacobsoni et la profondeur $\mathrm{B}$ des cellules de couvain non operculé. II n'y a pas de différence en fonction de la distance $A$ entre l'infestation des cellules raccourcies et celle des témoins (fig 2). Mais si l'on forme des groupes en fonction de la taille de la larve, l'infestation est plus forte (test de Wilcoxon, $P=0,01$ ) dans tous les groupes de cellules raccourcies (fig 3). L'infestation du couvain non operculé ne dépend donc pas de la taille de la larve, mais de la distance entre l'extrémité de la larve et l'ouverture de la cellule. II est donc peu vraisemblable que la quantité de phéromo- 
ne produite par les larves à un âge donné soit le seul stimulus (Trouiller et al, 1991) qui déclenche l'infestation des cellules de couvain. Que la distance A et l'infestation par $V$ jacobsoni soient liées peut être dû au fait que les cellules raccourcies sont operculées plus tôt (Goetz et Koeniger, 1992) ou que $V$ jacobsoni ne réagit à la présence des larves que lorsque la distance est supérieure à $3-5 \mathrm{~mm}$ (Issa et al, 1985).

Varroa jacobsoni / infestation / Apis mellifera / comportement d'operculation / phéromone

\section{Zusammenfassung - Strukturmerkma-} le der Zellen beeinflussen die Brutinvasion von Varroa jacobsoni. Zur Reproduktion dringen Varroa-Weibchen während des letzten Tages vor dem Verdeckeln in die Brutzellen ein (Ifantidis, 1988; Boot et $a l, 1990)$. Le Conte et al $(1989,1990)$ und Trouiller et al (1991) berichteten von der Isolation und Identifikation von Pheromonen, die das Verdeckeln auslösten und für Varroa attraktiv waren. Beim Verdeckeln der Brutzellen spielt aber außer Pheromonen auch der Abstand (A) zwischen Larve und Zellöffnung eine große Rolle (Goetz und Koeniger, 1992). Der Einfluß dieses Abstandes auf die Brutinvasion von Varroa wurde geprüft.

An offenen Brutzellen tiefgefrorener Waben eines mit Varroa infizierten Volkes wurde der Durchmesser der Zellöffnung und der Abstand $(A)$ gemessen, sowie der Varroa-Befall der einzelnen Zellen bestimmt (Abb 1). Die ersten Zellen befanden sich bei einem Abstand $A=5,5-5,0 \mathrm{~mm}$ bereits im letzten Stadium des Verdeckelns (Öffnung des Zelldeckels kleiner als $4 \mathrm{~mm}$ ). Die Brutinvasion der Milben beginnt etwas früher bei einem Abstand $A=$ 7,5-7,0 mm. Beide Kurven zeigen jedoch einen ähnlichen Verlauf, was einen Zuzammenhang zwischen dem Zellverdeckeln und dem Eindringen der Milben vermuten läßt.

An tiefgefrorenen Waben mit verkürzten Zellen (Goetz und Koeniger, 1992) und Kontrollzellen wurde der Abstand (A), die Zelltiefe (B) und der Varroa-Befall bestimmt. Bezüglich des Abstandes (A) gibt es zwischen verkürzten Zellen und Kontrollzellen keinen Unterschied im VarroaBefall (Abb 2). Vergleicht man dagegen verkürzte Zellen und Kontrollzellen mit Larven gleicher Größe, so zeigt sich in allen Gruppen ein höherer Befall von verkürzten Zellen (Abb 3). Der Befall offener Brutzellen hängt somit nicht von der Larvengröße sondern vom Abstand zwischen Larve und Zellrand ab. Es ist daher unwahrscheinlich, daß das Verdeckeln allein durch die von der Larve produzierte Pheromonmenge ausgelöst wird. Möglicherweise ist der Zusammenhang zwischen Abstand (A) und der Brutinvasion dadurch verursacht, da 3 die Milben nur bei einem Abstand kleiner als 3-5 mm auf Larven reagieren (Issa et al, 1985). Die Brutinvasion könnte auch direkt vom Verdeckeln ausgelöst werden, da Brutzellen mit einem verkürzten Abstand $A$ frühzeitig verdeckelt werden (Goetz und Koeniger, 1992).

Varroa jacobsoni / Invasion / Verdecklungsverhalten / Apis mellifera / Pheromone

\section{REFERENCES}

Boot WJ, Calis JNM, Beetsma J (1990) Invasion of Varroa mites in honeybee brood cells: observation of Varroa mite behaviour. In: Proc Int Symp Recent Research on Bee Pathology (Ritter W, ed) Apimondia Ghent, 43-44

Goetz B, Koeniger N (1992) Structural features trigger capping of brood cells in honey bees. Apidologie 23, 211-216 
Ifantidis MD (1988) Some aspects of the process of Varroa jacobsoni mite entrance into honey bee (Apis mellifera) brood cells. Apidologie 19, 387-396

Issa MRC, de Jong D, Gonzalves LS (1985) Untersuchung über das Vorziehen von Apis mellifera-Drohnen durch die Milbe Varroa jacobsoni. In: XXX Int Bienenzüchter Kongr. Apimondia, Bucharest, 169-170

Le Conte $Y$, Arnold G, Trouiller J, Masson C, Chappe B (1989) Attraction of the parasitic mite Varroa to the drone lavae of honey bees by simple aliphatic esters. Science 245 , 638-369

Le Conte Y, Arnold G, Trouiller J, Masson C, Chappe B (1990) Identification of a brood pheromone in honey bees. Naturwissenschaften 77, 334-336

Meyer W, Ulrich W (1952) Zur Analyse der Bauinstinkte unserer Honigbiene. Untersuchungen über die Kleinbauarbeiten. Naturwissenschaften 39, 264

de Ruijter A, Calis J (1988) Distribution of Varroa jacobsoni female mites in honey bee worker brood cells of normal and manipulated depth (Acarina: Varroidae). Entomol Gen 14, 107-109

Trouiller J, Arnold G, Le Conte Y, Masson C (1991) Temporal pheromonal and kairomonal secretion in the brood of honey bees. Naturwissenschaften $78,368-370$ 